Vol. 4, No. 2, Oktober 2020, hlm. 218-228 DOI: $10.37274 /$ rais.v4i02.338

\title{
Adab Berpakaian Wanita Muslimah Sesuai Tuntunan Syariat Islam
}

\author{
Syarifah Alawiyah ${ }^{1 *}$, Budi Handrianto', Imas Kania Rahman ${ }^{1}$ \\ ${ }^{1}$ Universitas Ibn Khaldun Bogor, Indonesia \\ *syarifah.dirham@gmail.com
}

\begin{abstract}
Abstrak
Fenomena yang melanda masyarakat Indonesia khususnya para pelajar muslimah adalah budaya berpakaian yang menyimpang dari tuntunan syariat Islam, meski masih ada wanita muslimah yang menunjukkan cara berpakaian yang sesuai syariat, tapi jumlahnya relatif sedikit dibandingkan yang belum sesuai. Fenomena berhijab pun saat ini masih belum sesuai dengan syarat pakaian wanita muslimah dimana tidak sedikit dari model pakaian yang dikenakan wanita berhijab tapi masih memperlhatkan bentu tubuh, berbahan transparan dan sebagainya. Tentu saja ini adalah permasalahan yang harus dibenahi oleh para orang tua, pendidik dan penanggung jawab pendidikan, karna jika dibiarkan hal ini akan menjadi budaya yang terus menerus akan berkembang dan akhirnya menjadi sebuah hukum yang dianggap benar oleh generasi mendatang. Salah satu cara mengatasinya adalah dengan menumbuhkan kesadaran di kalangan wanita muslimah tentang kewajiban menutup aurat dengan memberikan pemahaman yang cukup mengenai aurat, kewajiban menutupnya dan adab berpakaian dalam Islam. Penelitian ini menggunakan kajian pustaka yang mensintesa teori-teori dan konsep dari para ulama fiqih tentang aurat adab berpakaian dalam Islam yang kemudian menghasilkan konsep tentang bagaimana cara menumbuhkan kesadaran menutup aurat yang bisa diinternalisasikan dalam bentuk perilaku berpakaian pada wanita muslimah khususnya para pelajar.
\end{abstract}

Kata kunci: : adab berpakaian; wanita muslimah; aurat.

\begin{abstract}
The phenomenon that afflicts Indonesian society, especially Muslim female students, is a culture of clothing that deviates from the guidance of Islamic law, although there are Muslim women who show how to dress according to Sharia, but the number is relatively small compared to those who are not. The phenomenon of wearing hijab is currently not in accordance with the requirements of Muslim women's clothing where not a few of the clothing models worn by women wearing hijab but still show the shape of the body, made from transparent and so on. Of course this is a problem that must be addressed by parents, educators and those in charge of education, because if it is left unchecked this will become a culture that will continue to develop and eventually become a law that is considered true by future generations. One way to overcome this is to raise awareness among Muslim women about the obligation to cover their genitals by providing sufficient understanding of genitals, the obligation to cover them and the adab of dressing in Islam. This study uses a literature review that synthesizes the theories and concepts of figh scholars about the aurat adab dress in Islam which then produces a concept of how to foster awareness of covering one's genitals which can be internalized in the form of dress behavior in Muslim women, especially students.
\end{abstract}


Keywords: dress manners; Muslim women; genitals/aurat.

\section{Pendahuluan}

Islam adalah agama yang sangat memuliakan dan menghormati wanita, salah satu bentuk penghormatan dan pemuliaan Islam terhadap wanita adalah disyariatkannya perintah untuk menutup aurat bagi wanita yang batasannya berbeda dengan laki-laki. Jika seorang laki-laki muslim hanya cukup menutupi bagian tubuhnya sebatas lutut dan pusat (perut), maka Islam mewajibkan seorang muslimah yang telah baligh untuk menutupi seluruh bagian tubuhnya kecuali muka dan telapak tangan. Perintah ini bertujuan untuk menjaga harkat dan martabat wanita agar tetap terlindungi dan terpandang sebagai wanita baik-baik. Akan tetapi banyak dari kaum wanita yang masih belum memahami hakikat dari tujuan disyariatkannya perintah menutup aurat ini, sehingga tidak sedikit dari mereka yang enggan melaksanakan perintah Allah untuk menutup aurat, dengan kata lain kesadaran menutup aurat masih sangat rendah di kalangan wanita muslimah khususnya para pelajar (siswi) tingkat SMA/ SMK.

Dari hasil survey awal yang dilakukan penulis dengan cara sederhana melalui media on line diperoleh data bahwa jumlah siswi muslimah di SMK di beberapa wilayah Kabupaten Bogor yang sudah menutup aurat dengan cara memakai hijab di sekolah sudah terbilang tinggi yaitu pada kisaran di atas 90\%. Sementara untuk perkiraan jumlah siswa yang menutup aurat secara syar'i atau sesuai dengan ketentuan Islam tergolong masih cukup rendah yaitu di kisaran 30-40\%, sedangkan berdasarkan pengamatan guru PAInya yang sudah konsisten menutup aurat secara syar'i berada pada kisaran 15-20\%.

Penelitian serupa dilakukan oleh M. Nasir (2019), penelitian ini merupakan penelitian dengan library research yang membahas permasalahan tentang kewajiban menutup aurat bagi wanita muslimah yang sudah baligh dengan batas-batas dan ketentuan syariat Islam menurut pandangan para ulama berdasarkan dalil-dalil Al-quran dan sunnah rasul. Begitu pula artikel yang ditulis oleh Bahrun Ali Murtopo (2017) Sebuah penelitian yang membahas tentang bagaimana seharusnya seorang wanita muslimah berpakaian sesuai dengan ketentuan syariat Islam didasari atas kesadaran bahwa menutup aurat itu bukan hanya sekedar kewajiban belaka, akan tetapi lebih dari itu harus menyadari akan tujuan dan manfaat dari menutup aurat itu sendiri. Dalam artikel ini dibahas tentang ketentuan berpakaian baik dari sudut pandang budaya maupun agama Islam.

Berbeda dengan penelitian sebelumnya, penelitian ini akan melahirkan sebuah konsep tentang bagaimana seorang muslimah seharusnya berpakaian sesuai dengan tuntunan syariat Islam yang didasari atas kesadaran bahwa perintah mentup aurat merupakan kewajiban yang datang dari Allah swt dan harus dilaksanakan dengan 
kesadaran dan bukan atas dasar ikut-ikutan seperti yang terjadi kebanyakan di kalangan pelajar muslimah tingkat sekolah menengah (SMA/SMK).

Penelitian ini bertujuan untuk meningkatkan pemahaman pada pelajar muslimah khususnya tingkat SMA/ SMK tentang adab berpakaian dalam syariat Islam terlebih lagi memahami tujuan disyariatkannya perintah menutup aurat khususnya bagi wanita sehingga menumbuhkan kesadaran pada diri mereka akan pentingnya menjalankan perintah agama untuk menutup aurat yang mana pemahaman dan kesadaran tersebut dapat meningkat pada tahap internalisasi yaitu berpakaian dan berhias sesuai dengan tuntunan syariat Islam secara konsisten dalam setiap waktu, tempat dan keadaan bukan karena tren mode atau sekedar ikut-ikutan.

\section{Metode Penelitian}

Metode yang digunakan pada penelitian ini menggunakan pendekatan library research atau penelitian pustaka, yaitu pnelitian yang berusaha memfokuskan diri untuk menganalisis dan menafsirkan bahan tertulis atau literatur berupa buku-buku, artikel, situs wed, buku elektronik dan sumber tertulis lainnya (dokumen kepustakaan). Dengan demikian, jenis penelitian ini adalah penelitian kualitatif yang mensintesa konsep-konsep atau teori-teori dari berbagai sumber yang dikaji oleh penulis menjadi sebuah konsep baru.

\section{Hasil dan Pembahasan}

\section{A. Aurat wanita dan hukum menutupnya dalam Islam}

Kata aurat merupakan kata serapan yang berasal dari kata dalam bahasa Arab "'auroh" berasal dari bentuk fi'il madhi lafadz "'aaro". Sedangkan menurut Mahtuf Adnan dalam bukunya Risalah Fiqih Wanita, kata aurat berasal dari bahasa arab yang artinya kurang, jelek atau malu. Sedangkan jika diartikan secara syara' aurat adalah bagian tubuh yang tidak patut (pantas) untuk diperlihatkan kepada orang lain (kecuali pada suaminya atau kepada hamba sahaya perempuan atau sewaktu sendirian di ruang tertutup). (Ahnan: 2011).

Ummu Syafa Suryani Arfah dalam bukunya menjelaskan bahwa aurat adalah bagian tubuh manusia yang dilarang untuk diperlihatkan, kecuali apa yang diperbolehkan Allah dan rasul-Nya, atau juga bisa diartikan sebagai sesuatu yang jika ditampakkan akan menimbulkan aib (Ummu Syafa: 2015). Dalam surat al-Nūr: 58, kata "awrah" diartikan oleh mayoritas ulama tafsĩr sebagai sesuatu dari anggota badan manusia yang membuat malu jika dipandang. Sedangkan dalam surat al-Ahzâb: 13, kata "awrah" dirtikan sebagai cela yang terbuka terhadap musuh, atau cela yg memungkinkan orang lain mengambil kesempatan (Muhammad: 2001). 
Berdasarkan pendapat para ahli tersebut maka dapat disimpulkan bahwa aurat adalah bagian tubuh manusia yang menurut syariat Islam harus ditutup dengan pakaian yang memenuhi syarat dan tidak boleh diperlihatkan kepada orang lain.

M. Quraish Shihab dalam bukunya mengatakan bahwa syariat Islam mewajibkan kaum muslimin memakai busana yang menutup aurat dan sopan, baik laki-laki maupun perempuan. Terdapat perbedaan yang sangat jelas antara aurat laki-laki (muslim) dengan aurat wanita (muslimah) dalam hukum Islam, aurat laki-laki cukup sederhana, berdasarkan ijma ulama, auratnya sebatas antara di atas pusat dan kedua lutut (bayn alsurrat wa al-ruqbatayn). Sedang aurat wanita adalah segenap tubuhnya kecuali muka, telapak tangan dan telapak kakinya. Bahkan ada pendapat yang mengatakan bahwa seluruh tubuh wanita tanpa kecuali adalah aurat (Shihab: 2010).

Perintah menutup aurat ini khususnya bagi seorang muslimah yang sudah dewasa (baligh) tersurat dalam firman Allah yang tertuang dalam QS. Al-Ahzab (33) ayat 59 berikut ini:

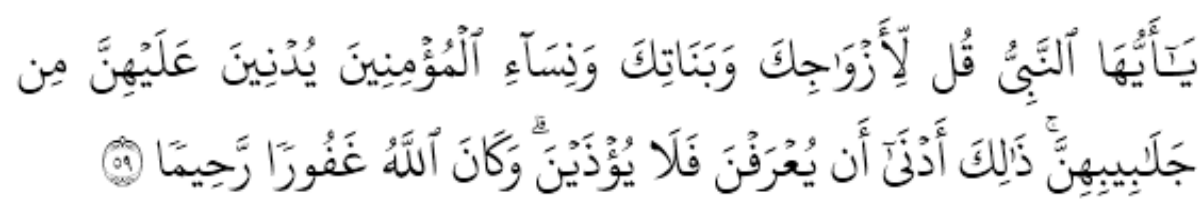

"Hai Nabi, katakanlah kepada isteri-isterimu, anak-anak perempuanmu dan isteriisteri orang mukmin: "Hendaklah mereka mengulurkan jilbabnya ke seluruh tubuh mereka". Yang demikian itu supaya mereka lebih mudah untuk dikenal, karena itu mereka tidak di ganggu. Dan Allah adalah Maha Pengampun lagi Maha Penyayang". (QS. Al-Ahzab (33): 59)

Ulama berbeda pendapat mengenai batas aurat wanita di depan mahramnya. AsySyafi'īyah mengatakan bahwa 'aurat wanita ketika berhadapan dengan mahramnya adalah antara pusat dengan lutut. Selain batas tersebut, dapat dilihat oleh muhrimnya dan oleh sesamanya wanita. Pendapat lain mengatakan bahwa seluruh anggota tubuh wanita adalah 'aurat di hadapan mahramnya, kecuali kepala (termasuk muka dan rambut), leher, kedua tangan sampai siku dan kedua kaki sampai lutut, karena semua anggota badan tersebut digunakan dalam pekerjaan sehari- hari.(An-Ramli: $\mathrm{tt}$ ). Hal tersebut sejalan dengan firman Allah yang terdapat dalam QS. An-Nur (24) ayat 31 berikut ini: 


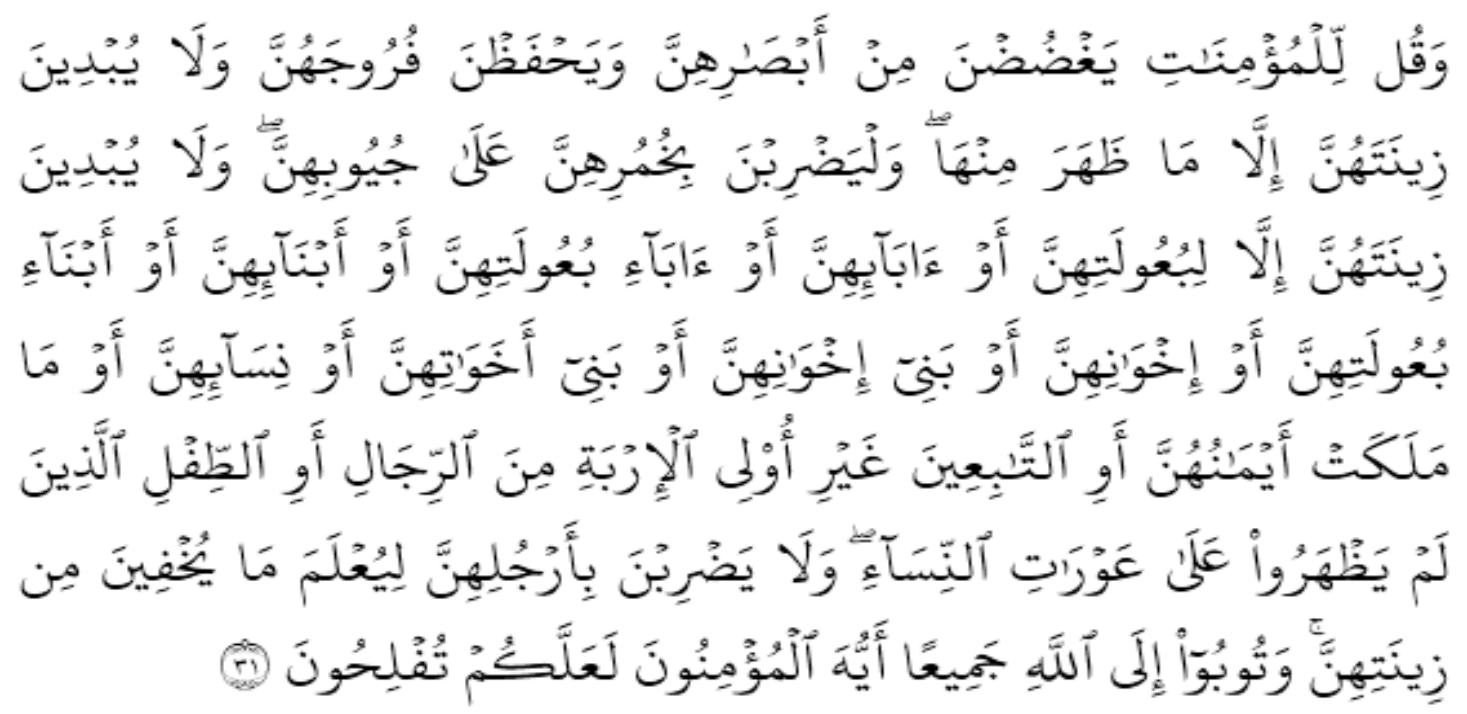

"Katakanlah kepada wanita yang beriman: "Hendaklah mereka menahan pandangannya, dan kemaluannya, dan janganlah mereka menampakkan perhiasannya, kecuali yang (biasa) nampak dari padanya. Dan hendaklah mereka menutupkan kain kudung ke dadanya, dan janganlah menampakkan perhiasannya kecuali kepada suami mereka, atau ayah mereka, atau ayah suami mereka, atau putera-putera mereka, atau putera-putera suami mereka, atau saudara-saudara laki-laki mereka, atau putera-putera saudara lelaki mereka, atau putera-putera saudara perempuan mereka, atau wanitawanita islam, atau budak-budak yang mereka miliki, atau pelayan-pelayan laki-laki yang tidak mempunyai keinginan (terhadap wanita) atau anak-anak yang belum mengerti tentang aurat wanita. Dan janganlah mereka memukulkan kakinyua agar diketahui perhiasan yang mereka sembunyikan. Dan bertaubatlah kamu sekalian kepada Allah, hai orang-orang yang beriman supaya kamu beruntung". (QS. An-Nur (24): 31)

Adapun yang dimaksud dengan mahram atau yang disamakan dengan itu sebagai yang tercantum dalam surah an-Nūr ayat 31 tersebut adalah; suami, ayah, ayah suami, putra laki- laki, putra suami, saudara laki-laki, putra saudara laki-laki, putra saudara perempuan, wanita, budaknya, pelayan laki-laki yang tak bersyahwat, atau anak yang belum mengerti tentang aurat wanita. Selain itu, dalam surat an-Nisā disebutkan pula saudara bapak dan saudara ibu.

Sementara itu, aurat wanita ketika berhadapan dengan orang-orang yang bukan mahramnya, menurut kesepakatan ulama adalah meliputi seluruh tubuhnya, selain muka, telapak tangan dan kakinya. Karena itulah, seorang laki-laki dapat saja melihat bagian-bagian tersebut pada tubuh wanita yang dilamarnya. Berdasarkan penjelasan ini, maka dapat disimpulkan bahwa batas aurat wanita pada saat berada di hadapan lakilaki non mahramnya adalah sama dengan ketika dalam keadaan salat. 
Seorang wanita muslimah jika berhadapan dengan laki-laki yang bukan mahramnya maka ia wajib menutup segenap tubuhnya selain muka dan kedua telapak tangannya. Ini berarti bahwa beberapa bagian tubuh yang termasuk aurat tersebut hanya wajib ditutup jika berhadapan laki-laki yang bukan mahram, tetapi ketika berhadapan dengan mahramnya sendiri bagian tubuh tersebut tidak menjadi 'aurat dan tidak wajib ditutup. Jadi, bagian-bagian tubuh tersebut sifat keauratannya tergantung pada keadaan atau biasa disebut 'aurat 'arìdī. Sedangkan aurat yang tidak tergantung pada keadaan disebut 'aurat zātī (Oktariadi: 2016).

Dengan demikian, sebagaimana dipahami dari Q.S. al-Nūr ayat 31, 'aurat 'arīdī dapat saja dilihat oleh pelayan laki-laki yang tidak punya syahwat dan anak-anak yang belum mengerti tentang 'aurat wanita, meskipun mereka laki-laki lain (bukan mahram), dan meskipun bukan dalam keadaan darurat. Namun jika dalam keadaan darurat, semua 'aurat baik zātī maupun 'arīdī dapat saja diperlihatkan. Menurut Abū Zahrah, menutup aurat jika dipandang dari ușul fiqh, dikategorikan dalam jenis kewajiban sekunder (wajib lighayrih), bukan kewajiban primer (wajib li zātī). Yang dimaksud dengan wajib lighayrih adalah sesuatu yang wajib karena berkaitan dengan kewajiban lain yang menjadi pokok . Dalam hal ini, menutup aurat menjadi wajib karena berkaitan dengan kewajiban pokok untuk menghindari perzinaan. Adapun dalam hal timbulnya suatu kesulitan meskipun tidak merupakan darurat, maka kewajiban menutup aurat dapat gugur, misalnya untuk kepentingan pengobatan.

Salah satu tujuan disyariatkannya kewajiban menutup aurat khususnya bagi wanita adalah dimaksudkan untuk membedakan antara wanita terhormat dan wanita jalanan. Hal ini berdasarkan sebab turunnya ayat tersebut. Menurut al-Qurțubī, ayat 59 surat al$A h z a \bar{b}$ itu turun sebagai teguran atas kebiasaan wanita-wanita Arab yang keluar rumah tanpa mengenakan jilbab. Karena tidak memakai jilbab, banyak laki-laki yang sering mengganggu mereka, dan melecehkan mereka seperti budak. Berkenaan dengan hal itu, maka turunlah ayat tersebut. (Al-Qurthubi: $\mathrm{tt}$ )

Dari keterangan-keterangan di atas dapat disimpulkan bahwa tujuan utama menutup aurat adalah sebagai benteng (perisai) bagi seorang wanita agar terhindar dari fitnah dan akhlak tercela ataupun kejahatan laki-laki. Karna pada hakikatnya Islam tidak menginginkan keburukan terjadi pada diri manusia, sehingga kepatuhan seseorang terhadap syariat dalam hal ini pada dasarnya akan berdampak kebaikan pada dirinya sendiri.

\section{B. Adab berpakaian bagi wanita muslimah}

Ketika kita berbicara tentang aurat, maka permasalahannya akan melebar kepada pembahasan pakaian, karena aurat adalah tubuh manusia yang harus ditutupi, sementara alat yang digunakan untuk menutupnya adalah pakaian. Sebab itulah Islam juga sangat memperhatikan tentang bagaimana seharusnya seorang muslim atau muslimah 
berpakaian dan berhias, hal ini juga dijelaskan secara rinci dalam syariat Islam melalui firman-firman Allah dalam Al-Quran yang diperjelas lagi dengan sabda-sabda rasulullah SAW.

Perintah untuk berbusana muslimah yang sesuai dengan ketentuan syariat Islam dikhususkan kepada kaum wanita dengan pertimbangan karena wanita akan selalu menjadi pusat perhatian. Oleh karena itu, di saat wanita yang sudah baligh berpergian keluar rumah maka wajib baginya untuk mengenakan busana yang sesuai dengan ketentuan syariat Islam, yakni pakaian yang menutup aurat. Sementara itu berpakaian sesuai dengan ketentuan syariat Islam harus memenuhi beberapa syarat tertentu. (Ahnan: 2011).

Menurut Maftuh Ahnan pakaian wanita muslimah ketika di luar rumah atau di hadapan laki-laki yang bukan mahram adalah "jilbab", yaitu pakaian yang dapat menutup tubuh dari kepala hingga kaki atau menutup sebagian besar tubuh sehingga yang tampak hanyalah muka dan telapak tangan saja (Ahnan: 2011). Istilah "jilbab" ini dikenal berasal dari firman Allah dalam QS. Al-Ahzab ayat 59 yang kemudian di negara kita lebih dikenal dengan "busana muslimah".

Adapun syarat-syarat pakaian wanita muslimah sesuai dengan syariat Islam menurut Syeikh Nashirudin Al-bani yang dijelaskan dalam buku risalah fiqih wanita yng ditulis oleh Maftuh Ahnan adalah sebagai berikut: 1) Menutup seluruh tubuh kecuali muka dan telapak tangan; 2) Berbahan tebal tidak tembus pandang (transparan) sehingga dapat memperlihatkan warna kulit; 3) Longgar dan tidak sempit (ketat) sehingga tidak menampakkan lekuk-lekuk tubuh; 4) Tidak menyerupai pakaian laki-laki (Larangan menyerupai di sini adalah keserupaan karena ingin berlagak seperti laki-laki pada umumnya atau menampakkan diri seperti laki-laki); 5) Tidak menyerupai pakaian wanita kafir dan wanita jahiliyah. Para wanita jahiliyah memakai kerudung tapi leher dan dada mereka tetap terlihat; 6) Tidak terlalu mencolok sehingga menarik perhatian orang yang melihatnya (syuhroh). Pakaian syuhroh adalah pakaian yang sengaja digunakan untuk memamerkan kebesaran dan kemasyhuran di tengah-tengah masyarakat; 7) Tidak diberi hiasan yang berlebihan, seperti warna warni yang berlebihan, menampakkan perhiasan dan menggunakan wewangian yang mencolok wanginya. (Ahnan: 2011)

Hijab yang sempurna (syar'i) sesuai dengan ketentuan-ketentuan syariat Islam yang tersebut di atas adalah yang dapat menutup semua anggota badan wanita. Hijab bukanlah semata-mata perhiasan tubuh saja, tidak berwarna mencolok dan mengundang perhatian, berbahan tebal dan tidak transparan sehingga tidak menampakkan warna kulit, longgar dan tidak ketat sehingga tidak menggambarkan bentuk tubuh wanita seperti yang diterangkan dalam Firman Allah SWT QS. Al-Ahzab ayat 59.

Al-Albani menjelaskan beberapa fenomena wanita masa kini dalam kebiasaan berpakaian yang harus diperbaiki, di antaranya sebagian besar muslimah sudah 
banyak yang menutupi bagian rambut dan dadanya, namun mereka masih memakai pakaian ketat, banyak dari mereka yang menutupi bagian paha sampai kakinya dengan celana ketat yang sewarna dengan kulitnya. Adapula yang memakai kerudung (khimar) tetapi tanpa dilengkapi jilbab. Masih banyak lagi fenomena lain yang serupa atau lebih parah di zaman sekarang. Tragisnya, masyarakat muslim menganggapnya sebagai busana muslimah dan simbol Islam, padahal hakikatnya adalah busana fitnah yang merupakan makar besar musuh-musuh Islam. (Fauzi: 2016)

Berdasarkan penjelasan mengenai adab berpakaian bagi wanita muslimah tersebut, maka seorang wanita muslimah yang mengaku dirinya beriman, hendaklah memperhatikan adab-adab tersebut ketika ia akan tampil di hadapan orang lain (laki-laki yang bukan mahram) dan ketika ia keluar rumah. Hendaklah para wanita muslimah menjaga kehormatan dirinya dari fitnah dan gangguan laki-laki dengan cara tampil dengan menggunakan pakaian yang syar'i (sesuai dengan ketentuan syariat Islam).

Dengan kata lain, wanita muslimah yang sudah mencapai usia baligh (dewasa), jika ia keluar rumah dan berhadapan dengan laki-laki yang bukan mahramnya dan berpakaian yang tidak memenuhi syarat-syarat tersebut di atas, maka menurut hukum Islam perbuatan itu termasuk dosa dan melanggar perintah Allah untuk menutup aurat dengan jilbab sesuai firman-Nya dalam QS. al-Ahzab ayat 59. Hal ini dapat terwujud dalam bentuk perilaku yang benar dari seorang muslimah jika ia memiliki kesadaran beragama yang cukup dalam menutup aurat, tentunya hal ini sangat dipengaruhi dengan tingkat pemahaman terhadap hukum islam tentang aurat, kewajiban menutupnya dan adab berpakaian sesuai dengan ajaran Islam.

\section{Kesadaran Menutup Aurat}

Kesadaran menutup aurat merupakan perwujudan dari kesadaran beragama seseorang, maka tidak ada indikator yang mengarah secara khusus tentang kesadaran menutup aurat ini, untuk itu penulis mencoba menurunkannya dari indikator kesadaran beragama yang dikaitkan dengan kewajiban menutup aurat.

Kesadaran beragama meliputi rasa keagamaan, pengalaman ke-Tuhanan, keimanan, sikap dan tingkah laku keagamaan yang terorganisasi dalam sistem mental dari kepribadian. Karena agama melibatkan seluruh fungsi jiwa-raga manusia, maka kesadaran beragama pun mencakup aspek-aspek afektif, kognitif dan motorik. Keterlibatan fungsi afektif terlihat didalam pengalaman ke-Tuhanan, rasa keagamaan dan kerinduan kepada Tuhan. Aspek kognitif nampak dalam keimanan dan kepercayaan. Sedangkan keterlibatan fungsi motorik nampak dalam perbuatan dan gerakan tingkah laku keagamaan.

Kesadaran beragama meliputi banyak hal yang mencerminkan ketaatan manusia dalam menjalankan ajaran agamanya, bisa dalam wujud menjalankan perintah dan menghindari larangan Allah. salah satu bentuk kesadaran beragama dalam wujud 
menjalankan perintah yaitu menutup aurat bagi wanita, kesadaran beragama dalam menutup aurat merupakan suatu perbuatan menutup aurat yang diwajibkan kepada muslimah dengan dilandasi dari kepercayaan terhadap ajaran Islam, perasaan yakin dan nyaman dalam menutup aurat dan melakukannya sebagai sebuah kewajiban yang berasal dari keinginan dan keinsafan pribadi.

Sikap keagamaan atau kesadaran beragama seseorang menurut Djamaluddin Ancok dapat dilihat dari lima aspek sebagai berikut: 1) Dimensi keyakinan (ideologis) yang disejajarkan dengan akidah; 2) Dimensi peribadatan (ritualistik) yang disejajarkan dengan syariah; 3) Dimensi penghayatan (eksperiensal) atau pengalaman-pengalaman religius; 4) Dimensi pengetahuan; 5) Dimensi pengamalan (konsekuensial) yang disejajarkan dengan akhlak. (Anchok: 2005).

Berdasarkan penjelasan di atas mengenaai kesadaran beragama maka dapat disimpulkan bahwa kesadaran menutup aurat adalah keadaan seseorang yang mengerti bahwa menurut hukum Islam ada beberapa bagian tubuh manusia yang tidak boleh diperlihatkan kepada orang lain (aurat) sehingga menumbuhkan perilaku menutup aurat dengan didasari atas keinsafan diri untuk menaati syariat agamanya tersebut.

Sesuai dengan pengertian di atas maka dapat dipahami bahwa menutup aurat harus didasari atas kesadaran diri bahwa itu merupakan kewajiban seorang muslim dan sebagai bentuk ketaatan terhadap hukum atau syariat agama Islam yang dianutnya bukan atas dasar keterpaksaan karena mematuhi perintah orang lain, atau hanya sekedar ikut-ikutan tanpa mengetahui.

Seorang muslimah dapat dikatakan memiliki kesadaran menutup aurat yang tinggi jika dapat menunjukkan indikator-indikaator sebagai berikut: 1) Keterlibatan fungsi kognitif dalam menutup aurat, yaitu berupa kepercayaan dan keimanan pada kewajiban untuk menutup aurat; 2) Keterlibatan fungsi afektif dalam menutup aurat, yang berupa pengalaman ketuhanan dan rasa keagamaan; 3) Keterlibatan fungsi psikomotor dalam menutup aurat, yaitu berupa perilaku sehari-hari yang merupakan perwujudan dari keterlibatan fungsi aspek kognitif dan afektifnya dalam menutup aurat yang ditunjukkan dengan cara berpakaian sesuai syariat Islam.

\section{Kesimpulan}

Cara berpakaian bagi wanita muslimah yang sudah baligh yang dibenarkan adalah bukan berdasarkan atas adat istiadat atau kebiasaan yang berlaku di kalangan masyarakat sesuai zamannya, bahkan bukan pula mengikuti tren mode yang sedang berkembang pada waktu dan tempat tertentu. Kecenderungan cara berpakaian yang seperti ini merupakan hal yang keliru yang berkembang di masyarakat Indonesia terutama di kalangan wanita muslimah dewasa ini karna berpakaian dalam Islam harus memperhatikan tatacara yang dibenarkan oleh syariat dengan memenuhi persyaratan 
persyaratan berikut: menutup aurat, berbahan tebal tidak transparan, tidak ketat atau membentuk lekuk tubuh, tidak menyerupai laki-laki, tidak menyerupai pakaian wanita kafir atau jahiliyah, tidak berlebihan hingga menunjukkan ketenaran dan tidak memakai wewangian yang menarik perhatian.

Kesadaran dalam menutup aurat merupakan unsur inti dari munculnya perilaku berpakaian yang sesuai dengan tuntunan syariat yaitu tertutupnya aurat dan terpenuhinya syarat-syarat seperti yang telah dijelaskan sebelumnya. Untuk itu yang perlu diperhatikan oleh para orang tua, pendidik dan penanggung jawab pendidikan adalah menumbuhkan kesadaran tersebut di kalangan wanita muslimah khususnya para pelajar.

Hendaknya para wanita muslimah menjadikan adab berpakaian dan ketentuanketentuan di atas sebagai tolok ukur dalam berpenampilan dan berhias agar terlihat perbedaan antara wanita muslimah dengan wanita non muslimah, bahkan agar terlihat identitas seorang muslimah sebagai wanita terhormat dan baik-baik, hendaknya para orang tua juga mengajarkan kepada para anak gadis mereka agar membiasakan diri sejak dini untuk berpakaian sesuai dengan ketentuan syariat supaya mereka terhindar dari perilaku kejahatan khususnya kejahatan seksual.

\section{Daftar Pustaka}

Ahnan, Mahtuf, Dkk, Risalah Fiqih Wanita, Surabaya: 2011, Terbit Terang

Al-Husaynī, Kifayatul al-Akhyar, Juz. I, (Kairo: Isa al-Halabī, t.t)

Ali, Muhammad dan Ibnu Muhammad, Hijab Risalah Tentang Aurat, Yogyakarta: Pustaka Sufi, 2002

Al-Qurțubī, Tafsir al-Qurțubī, Jilid VI, Kairo: Dār al-Sya'b, t.t

Ancok, Djamaluddin, dan Fuad Nashori Suroso, Psikologi Islam: Solusi Islam akan problem psikologi, Yogyakarta: Pustaka Pelajar, 2005, cet. I,

An-Ramli, Nihayat al-Muhtajj, Juz IV, Kairo: Mustafa al-Halabī, tt.

Arfah, Ummu Syafa Suryani, Dkk, Menjadi Wanita Shalihah, Jakarta: 2015, Eska Media

Baso, Mutmainnah, Aurat dan Busana, (Jurnal Al-Qadau, Vo. 2, no. 2: 2015)

Budiman, Haris, Kesadaran Beragama Pada Remaja Islam, (Al-Tadzkiyyah: Jurnal Pendidikan Islam, Volume 6, Mei 2015)

Daud, Fathonah K., Jilbab, Hijab Dan Aurat Perempuan (Antara Tafsir Klasik, Tafsir Kontemporer dan Pandangan Muslim Feminis), (AL-HIKMAH Jurnal Studi Keislaman, Volume 3, Nomor 1, Maret 2013)

Departemen Agama RI, Mushaf Al-Quran Terjemah, Jakarta: 2002, Pena Pundi Aksara

Dr. Zainal Abidin Arief, M.Sc, Metodologi Penelitian Pendidikan: Persfektif Paradigma Baru Dalam Penelitian Pendidikan, Bogor: 2014, Graha Widya Sakti.

Habibah, Syarifah, Sopan Santun dalam Berpakaian, (Jurnal Pesona Dasar Universitas Kuala, Vol. 2 No.3, Oktober 2014)

Hasanah, Hasyim, Peran Strategis Aktifis Perempuan Nurul Jannah Al-Firdaus dalam Membentuk Kesadaran Beragama Masyarakat Miskin Kota, (INFERENSI: Jurnal 
Penelitian Sosial Keagamaan, Volume 7, No. 2, Desember 2013)

Ibnu, Muhammad dan Muhammad Ali, Hijab Risalah Tentang Aurat (Yogyakarta: Pustaka Sufi, 2002)

Mughniyah, Muhammad, Jawad Fiqih Lima Mazhab, terj. Masykur A. B. Afif Muhammad, Idrus al-Kaff, (Jakarta: Lentera, 2001)

Muhammad, Husein, Fiqh Perempuan: Refleksi Kiyai atas Wacana Agama dan Gender, Yogyakarta: LKIS, 2001

Murtopo, Bahrun Ali, Etika Berpakaian dalam Islam; Tinjauan Busana wanita Sesuai dengan ketentuan islam ${ }_{2}$ (Tajdid: Jurnal Pemikiran Keislaman dan Kemanusiaan, Vol. 1 No. 2 Oktober 2017)

Nasir, M., Sudut Pandang Feminis Muslim tentang Menutup Aurat, (Jurnal Al-Qadau vol. 6 no. 1 Juni 2019)

Noer, Ali, Dkk, Pengaruh Pengetahuan Berjilbab dan Perilaku Keagamaan Terhadap

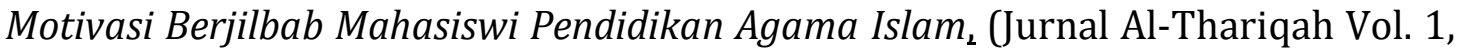
No. 2, Desember 2016)

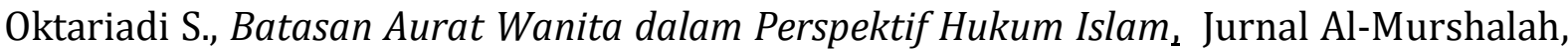
Vol. 2, No. 1, Januari - Juni 2016

R. Magdalena, Kedudukan Perempuan dalam Perjalanan Sejarah, (Harkat an-Nisa: Jurnal Studi Gender dan Anak, Vol. II, No. 1, 2017) 